\title{
Internal control: strengthening policy enging in non-profit organizations
}

\section{Control interno: fortalecimiento en aplicación de políticas en las organizaciones sin fines de lucro}

HERRERA-FREIRE, Alex Humberto ${ }^{*}$, HERRERA-FREIRE, Alexander Geovanny, TUAREZSOLORZANO, Diana Elizabeth and TRIANA-JIMENEZ, Katherin Yessenia

Universidad Técnica de Machala, Ecuador.

ID $1^{\text {st }}$ Author: Alex Humberto, Herrera-Freire / ORC ID: 0000-0002-3345-8726

ID $1^{\text {st }}$ Co-author: Alexander Geovanny, Herrera-Freire / ORC ID: 0000-0003-4039-1029

ID $2^{\text {nd }}$ Co-author: Diana Elizabeth, Tuarez-Solorzano / ORC ID: 0000-0003-2455-844X

ID $3^{\text {rd }}$ Co-author: Katherin Yessenia, Triana-Jimenez / ORC ID: 0000-0001-9422-8943

DOI: $10.35429 / J M P C .2021 .19 .7 .1 .6$

Received January 10, 2021; Accepted June 30, 2021

\begin{abstract}
The purpose of this research is to determine the strengthening that non-profit organizations obtain through the application of internal control policies, that is to say the internal control of the institutions will be analyzed, because it is an indispensable tool for the development of administrative management, financial and accounting, allowing reasonable security for the fulfillment of institutional goals. A research study was carried out using the descriptive methodology, so the reading of scientific articles and the bibliographic review was carried out, obtaining information on the strengthening and importance of internal control policies in non-profit organizations. On the basis of the research carried out, it was found that many of the organizations do not have a specific control policy, and this would result in inefficiency and inefficiency in the operations they carry out causing them weaknesses. With a good internal control system, it helps them to develop guidelines and compliance standards so that procedures and activities are carried out efficiently and effectively, allowing no errors and fraud to be reported.
\end{abstract}

Internal control, Strengthening, organizations, Financial management, Reasonableness, Accounting policies

\section{Resumen}

El propósito de esta investigación es determinar el fortalecimiento que obtienen las organizaciones sin fines de lucro mediante la aplicación de políticas de control interno, es decir se analizará el control interno de las instituciones, por ser una herramienta indispensable para el desarrollo de la gestión administrativa. , financiera y contable, permitiendo una seguridad razonable para el cumplimiento de las metas institucionales. Se realizó un estudio de investigación utilizando la metodología descriptiva, por lo que se realizó la lectura de artículos científicos y la revisión bibliográfica, obteniendo información sobre el fortalecimiento e importancia de las políticas de control interno en organizaciones sin fines de lucro. A partir de la investigación realizada, se encontró que muchas de las organizaciones no cuentan con una política de control específica, lo que se traduciría en ineficiencia e ineficiencia en las operaciones que realizan provocándoles debilidades. Con un buen sistema de control interno, les ayuda a desarrollar lineamientos y estándares de cumplimiento para que los procedimientos $\mathrm{y}$ actividades se lleven a cabo de manera eficiente y efectiva, permitiendo que no se reporten errores y fraudes.

Control interno, $\quad$ Fortalecimiento,
Organizaciones, Gestión
Razonabilidad, Políticas contables

Citation: HERRERA-FREIRE, Alex Humberto, HERRERA-FREIRE, Alexander Geovanny, TUAREZ-SOLORZANO, Diana Elizabeth and TRIANA-JIMENEZ, Katherin Yessenia. Internal control: strengthening policy enging in non-profit organizations. Journal of Microfinance Planning and Control. 2021. 7-19:1-6.

\footnotetext{
* Correspondence to the Author (Email: ahherrea@utmachala.edu.ec)

$\uparrow$ Researcher contributing as first author.
} 


\section{Introduction}

All organizations must contain mechanisms that help them identify different activities and processes that affect them in their environment, determining controls to minimize or avoid risks by taking action to achieve the goals and objectives proposed in the organization (Rodríguez, Piñeiro, \& Llano, 2013).

Internal control has long been recognized as fundamental and indispensable in organizational activities and in the practice of auditing (Rivas, 2011).

Modernization, the globalization of the economy and competition in the environment have evolved intensely, and therefore there was a need to design and implement internal control procedures and policies to secure and safeguard assets.

Internal control is a tool that covers all the processes carried out by the officials of the organizations, designed to address the risks and ensure that the management objectives are achieved, on the other hand, the application of an internal control manual requires the personnel who work, a commitment, systematic planning and respective verification of compliance with each policy.

Where administrative management is responsible for properly understanding the importance of implementing an internal control system, constituting a key factor in the objective of using efficient and efficient resources; thus, reducing losses incurred for different causes such as money diversion, accounting fraud, and others (Serrano, Señalin, Vega, \& Herrera, 2018).

An internal control manual can be applied to all the areas of operation of an organization, its effectiveness depends on the management achieving its established objectives and also obtaining information necessary for decision-making and alternatives that improve or convince the economic entity (Vega de la Cruz \& Ortiz, 2017).
This research focuses on a search for information on the growth of non-profit organizations, through the application of accounting policies, with this leading to a comparison with the information obtained in the project of linkage of the Technical University of Machala carried out in Puerto El Conchero belonging to the parish of Tenguel in the province of Guayas.

With the objective "to determine the strengthening of non-profit organizations through the application of internal control policies in organizations for the proper development of administrative, financial and accounting management".

This research develops a brief introduction on "Strengthening non-profit organizations through the application of control policies", then describes the methodology used to obtain the results. then the conceptual framework concerning the topic to be dealt with is developed with relevant information of the last five years, finally the conclusions are drawn up.

\section{Materials and methods}

The methodology applied in the following research is descriptive, because scientific articles were read and the bibliographic review consisting of obtaining information on the strengthening and importance of internal control policies in non-profit organizations.

The analytical-synthetic method, because the collection of documentary information was used based on the bibliography presented, thus analyzing the different aspects to reflect it in this research study (Gamboa, Puente, \& Vera, 2016).

\section{Conceptual framework}

Internal control is a tool that helps organizations evaluate efficiency, effectiveness, economy and productivity, achieving their objectives and goals set in accordance with the rules and regulations. It should be mentioned, in addition, that it allows to minimize risks, errors or irregularities in order to help make decisions to senior management (Obispo \& Gonzales, 2015). 
It should be noted that internal control is one of the most well-developed and important processes in an economic entity because it operates under many horizons the main one is that it ensures the data generated by the business information systems. ensuring procedures of truthfulness and relevance (Navarro \& Ramos, 2016).

By carrying out a good Internal Control System, it allows organizations to have a greater chance of being able to achieve the three categories of objectives: Effectiveness and efficiency of operations, reliability of operations, compliance with existing legal regulations and safeguarding assets (Robalino, Sanandrés, \& Ramírez, 2018).

In the internal control manual, procedures and policies of the accounting accounts should be established to serve as supporting instruments, which systematically contain the steps to be taken for the records of each operation of the organization (Vivanco, 2017).

The development of procedures and policies in the internal control manual should be an improvement in the organization, in order to be able to assess the existence or otherwise of a risk, focusing on the prevention of the misuse of resources. Internal control is therefore carried out to provide reasonable security for the achievement of the objectives (Novo, 2016).

The internal control contains four phases aimed at the establishments of the contexts in an initial preparation, planning of the actions, implementation of evaluation and adjustment of actions, this control is carried out by professionals who exercise the audit providing reasonable security for the achievement of the objectives of the organization (Vega de la Cruz $\&$ Nieves, 2016).

The auditor must have knowledge of the procedures also includes adequate preparation in relation to the reviews of the financial statements and sufficient knowledge in the specific economic area, which provides an ethical service based on practices, legislation, and techniques (Escalante D., 2014).
Although there are limitations in the management of internal control that prevent the objectives set out, since errors can be made in the application of this control, considering that the instructions are not understood, existence of incorrect judgments, negligence, or distraction (Robalino, Sanandrés, \& Ramírez, 2018).

It should be added that if constraints are considered and can be avoided, it would help to obtain optimal management, thus generating benefits for the administration of the organization, as in all activities that are carried out achieving the objectives set.

It is now essential to have an internal audit which is the result of organizational difficulties that have arisen in recent years, with internal audit being an independent and objective activity that allows the assurance of assets and the improvement of the operations of an organization, this will help it meet its objectives by providing a systematic and disciplined approach to evaluating and improving the effectiveness of each process (Hernández, 2016).

It should be noted that an internal control system consists of 5 components that are significant, these are: Control environment, risk assessment, control activities, information, communication and supervision.

The control environment component refers to the research base to be able to meet the objectives set in the organization, since it has a direct influence on the level of staff awareness of control (Sanmiguel, Valencia, Erazo, \& Ospina, 2015). Within this component are factors such as: The management philosophy, the attention and guidance provided by the board of directors, and the operational style, as well as when management assigns responsibilities and organizes staff.

The second risk assessment component refers to the identification and analysis of the risks that can be found when the objectives are achieved. COSO proposes to identify and assess the risks of the organization such as fraud, noncompliance with financial regulations, or disclosure of reliable or private information (Castañeda, 2014). The structure of the component are as follows: identify risk and detect change, determine the objectives of risk control and prevention. 
Control activities are those policies and procedures that help ensure that management guidelines are carried out, that is, this component ensures that the objectives and goals of the organization can be met. Among the control activities within COSO are: High-level reviews, information processing, direct functions or administrative activities, physical controls, performance indicators and segregation of responsibilities (Quinaluisa, Ponce, Muñoz, Ortega, \& Pérez, 2018).

To carry out this component they must agree with the type of organization and similarly staff must perform the activities established by the organization to be able to meet the objectives effectively.

Information and communication are the set of procedures, which provide information for good decision-making for the best management of organizations, that is to say that this helps to generate relevant information and communicate in a timely manner in order to fulfill their responsibilities. By carrying out a good and effective internal control system, it makes it possible for the information to be of quality and to carry out a good internal and external communication system (Castañeda, 2014).

Monitoring helps detect errors and irregulars that were not detected with control activities, as well as allows for necessary corrections and modifications (Vega de la Cruz, Pérez, \& Nieves, 2017). This component should take into account the scope and frequency of the evaluation, the evaluation process, the evaluation methodology and the level of documentation.

\section{Global Internal Control System}

In Spain, the model of internal control contained by organizations under the Coso model is found inefficiently, because instead of segregation of duties there is an accumulation of tasks, where the control mechanism does not seem to act in a responsible manner (Miaja, 2010). In the province of Cienfuegos, Cuba, they indicate that the existence of procedural or policy manuals allows organizations to know whether they handle operations in accordance with the internal control system, in this way, allowing organizations to achieve the goals and objectives set forth (Fuentes, Chapis , \& Chapis, 2019)
In Colombia, the application of internal control policies in the various organizations regardless of whether they are small or medium, are of great importance, because these policies help you measure efficiency and productivity, leading them to accurately measure the actual situation of the same (Salcedo Z. , 2018).

The implementation of internal control, in Colombia through the MECI, helps to promote mechanisms of leadership and communication, monitoring of the activities of the organizations, but also emphasizes the commitment of the senior management to achieving change in the organizations and their improvement (Montiel, Montiel , \& Montiel, 2017).

In Ecuador, not all organizations have a manual of accounting policy procedures, because they do not give the greatest importance to this document which is a tool that would help them avoid mistakes and fraud at the time, they present the financial information. they also allow for continuous improvement in the operations of each department of the organization, an entity must have a policy and procedures manual for each department, quality manual, organization manual (organizational culture), methods manual and other manuals required by the organization to meet its objectives.

Establishing accounting policies helps safeguard assets and the confidentiality of financial information, a manual is intended to serve as a guide to employees, helping to perform tasks quickly and efficiently (Salcedo N., 2019).

In Ecuador, the economic increase of the organizations has been developing year after year, due to the growth of the different activities, having as priority the organizational direction, is hence the main problem for the Ecuadorian organizations, is that they do not give importance to the internal controls, this affects the outcome of the financial statements. Therefore, he implemented a manual of internal control in the Ecuadorian organizations helps him to improve it, correcting errors, carrying out management of important methods, procedures that generate changes and achieve the objectives set by the organizations (Otmara, Lopez, \& Pèrez, 2017).
HERRERA-FREIRE, Alex Humberto, HERRERA-FREIRE, Alexander Geovanny, TUAREZ-SOLORZANO, Diana Elizabeth and TRIANA-JIMENEZ, Katherin Yessenia. Internal control: strengthening policy enging in non-profit organizations. Journal of Microfinance Planning and Control. 2021 


\section{Result}

The investigation was able to determine that policies and procedures exist but are not created in a document such as an internal control manual. approved by the partners that allow area managers to evaluate the effectiveness of internal control based on the identification and effective management of the risks inherent in the various activities that are constantly being carried out.

Non-profit organizations have been experiencing problems in accounting account management because of inadequate treatment, leading to results in the unreasonable financial statements. similarly, this does not allow them to avoid in time the lack of control and diversion of material and economic resources.

\section{Conclusion}

It was found that in non-profit organizations there are shortcomings in control policies and procedures, because not all organizations have an internal Control Manual, which means that these are weaknesses for organizations, causing inefficiency and inefficiency in operations, without being able to achieve the stated goals and objectives.

The internal control system is intended that organizations can achieve their objectives effectively and efficiently, for decision-making, providing reasonable security, with compliance with existing regulations and be able to safeguard assets.

\section{References}

Castañeda, L. I. (Enero-Diciembre de 2014). Los sistemas de control interno en las Mipymes y su impacto en la efectividad empresarial. Revista de Investigación de Administración, Contabilidad, Economía y sociedad(2), 129-146. Obtained from:

https://www.redalyc.org/articulo.oa?id=5518/5 51856273008

Escalante D., P. (2014). Auditoría financiera: Una opción de ejercicio profesional independiente para el Contador Público. Actualidad contable Faces, 17(28), 40-55. Obtained from: https://www.redalyc.org/pdf/257/25731098004. pdf
Fuentes, D., Chapis , E., \& Chapis, E. (2019). COMPORTAMIENTO ACTUAL DE LOS MANUALES DE PROCEDIMIENTOS EN LA PROVINCIA DE CIENFUEGOS, CUBA. Universidad y Sociedad, 11(3), 186-189. Obtained from: http://scielo.sld.cu/scielo.php?script=sci_arttext \&pid=S2218-36202019000300186

Gamboa, J. E., Puente, S. P., \& Vera, P. Y. (2016). Importancia del control interno en el sector público. Publicando, 3(8), 487-502. Obtained

from: https://dialnet.unirioja.es/servlet/articulo?codig $\mathrm{o}=5833405$

Hernández, O. (2016). La auditoría interna y su alcance ético empresarial. Actualidad Contable FACES, 19(33), 15-41. Obtained from: https://www.redalyc.org/pdf/257/25746579003. pdf

Miaja, M. (Enero-agosto de 2010). 207Las tendencias actuales en los sistemas de control interno de las organizaciones. Implicaciones para las Administraciones Públicas. Revista Documentacion Administrativa, 207-238. Obtained from: http://revistasonline.inap.es/index.php/DA/articl e/view/9670/9739

Montiel , M., Montiel , C., \& Montiel , O. (2017). ¿La implementación del control interno fortalece la gobernabilidad en las alcaldías municipales en Colombia? Administracion \& Desarrollo , 47(1), 97-117. Obtained from: https://dialnet.unirioja.es/servlet/articulo?codig $\mathrm{o}=6403441$

Navarro, F., \& Ramos, L. M. (2016). El control interno en los procesos de produccion de la industria litográfica en Barraquilla. Equidad \& Desarrollo(25), 245-267. doi:doi: http://dx.doi.org/10.19052/ed.3473

Novo, C. (Noviembre-Febrero de 2016). Procedimiento de control interno para el ciclo de inventario . $3 C$ Empresa: Invetigaión y pensamiento crítico, 5(4), 32-40. doi:http://dx.doi.org/10.17993/3cemp.2016.050 428.32-40
HERRERA-FREIRE, Alex Humberto, HERRERA-FREIRE, Alexander Geovanny, TUAREZ-SOLORZANO, Diana Elizabeth and TRIANA-JIMENEZ, Katherin Yessenia. Internal control: strengthening policy enging in non-profit organizations. Journal of Microfinance Planning and Control. 2021 
Obispo, D., \& Gonzales, Y. G. (2015). Caracterización del control interno en la gestión de las empresas comerciales del Perú 2013. In Crescendo, 6(1), 64-73. doi:https://doi.org/10.21895/incres.2015.v6n1.0 7

Otmara, S., Lopez, M., \& Pèrez, J. (JulioSeptiembre de 2017). NORMAS DE CONTROL CONTABLE: OPERACIÓN IMPRESCINDIBLE EN LA GESTIÓN EMPRESARIAL: UN CASO ECUATORIANO. Revista Universidad y sociedad, 9(3), 46-51. Obtained from: http://scielo.sld.cu/scielo.php?pid=S221836202017000300007\&script=sci_arttext\&tlng= $\mathrm{pt}$

Quinaluisa, N. V., Ponce, V. A., Muñoz, S. C., Ortega, X. F., \& Pérez, J. A. (enero-junio de 2018). El control interno y sus herramientas de aplicación entre COSO y COCO. Cofin, 12(1), 268-283. Obtained from: http://scielo.sld.cu/scielo.php?script=sci_arttext \&pid=S2073-60612018000100018

Rivas, G. (Julio-diciembre de 2011). Modelos contemporáneos de control interno. Fundamentos teóricos . Observatorio Laboral Revista Venezolana, 4(8), 115-136. Obtained from:http://servicio.bc.uc.edu.ve/faces/revista/l ainet/lainetv4n8/art6.pdf

Robalino, A. P., Sanandrés, L. G., \& Ramírez, A. d. (Abril de 2018). Control Interno como herramienta para la gestión administrativa caso de estudio Cooperativa SUMAC LLACTA. Revista Observatorio de la Economía Latinoamericana. Obtained from: https://www.eumed.net/rev/oel/2018/04/control -interno-sumacllacta.html

Rodríguez, M., Piñeiro, C., \& Llano, P. (2013). Mapa de Riesgos: Identificación y Gestión de Riesgos. Revista Atlantica de Economía, 2, 1-30. Obtained from: http://www.unagaliciamoderna.com/eawp/colda ta/upload/mapa_de_riesgos_19_06_13.pdf

Salcedo, N. (junio de 2019). Elaboracion de un manual de politicas contbales para la empresa QUITOSECURITY CIA. LTDA. Obtained from: http://repositorio.puce.edu.ec/bitstream/handle/ 22000/17275/Trabajo\%20de\%20TitulaciónPUCE- .pdf? sequence $=1 \&$ is Allowed $=y$
Salcedo, Z. (Mayo de 2018). EXIGENCIA DE IMPLEMENTAR LOS PROCESOS DE CONTROL INTERNO EN LASORGANIZACIONES. Obtenido deEXIGENCIA DE IMPLEMENTAR LOS PROCESOS DE CONTROL INTERNO EN LASORGANIZACIONES:

https://repository.unimilitar.edu.co/handle/1065 $4 / 17657$

Sanmiguel, F. M., Valencia, L. J., Erazo, W., \& Ospina, Y. (2015). Diseño de un sistema de control interno para el departamento contable de la empresa Gamatelo S.A, basado en la metodología "COSO". Revista de investigación en ciencias estratégicas, 2(1). Obtained from: https://revistas.upb.edu.co/index.php/RICE/arti cle/view/4512

Serrano, P. A., Señalin, L. O., Vega, F. Y., \& Herrera, J. N. (2018). El control interno como herramienta indispensable para una gestion financiera y contable eficiene en las empresas bananeras del canton Machala (Ecuador). Espacios, 39(3), 30. Obtained from: https://www.revistaespacios.com/a18v39n03/a1 8v39n03p30.pdf

Vega de la Cruz, L. O., \& Nieves, A. F. (2016). Procedimiento para la Gestión de la Supervisión y Monitoreo del Control Interno. Ciencias Holguin, 22(1), 1-19. Obtained from: https://www.redalyc.org/pdf/1815/1815435770 07.pdf

Vega de la Cruz, L. O., \& Ortiz, A. (2017). Procesos más relevantes del control interno de una empresa hotelera. Semestre Economico, 20(45), 217-231. doi:DOI: $10.22395 /$ seec.v20n45a8

Vega de la Cruz, L. O., Pérez, M. C., \& Nieves, A. F. (Julio-Diciembre de 2017). Procedimiento para evaluar el nivel de madurez y eficacia dl control interno. Revista Cientifica, 21(2), 212$230 . \quad$ Obtained from: https://revistacientifica.fce.unam.edu.ar/index.p hp?option=com_content $\&$ view $=$ article $\&$ id $=440$ \&Itemid=96

Vivanco, M. E. (2017). Los manuales de procedimientos como herramientas de contol interno de una organizacion. Universidad y Sociedad, 9(3), 247-252. Obtained from: http://scielo.sld.cu/pdf/rus/v9n3/rus38317.pdf 